\title{
PETROGRAFIA DE DUAS OCORRÊNCIAS DE PROVÁVEL ECLOGITO EM BODOCÓ E FLORESTA NO ESTADO DE PERNAMBUCO, BRASIL*
}

\author{
HARTMUT BEURLEN** e HUGO SÉRGIO VILLARROEL**
}

\begin{abstract}
PETROGRAPHY OF TWO OCCURRENCES OF PROBABLE ECLOGITES AT BODOCO AND FLORESTA, STATE OF PERNAMBUCO, BRAZIL. Petrographic investigations on two Ti mineralizations at Bodocò and Floresta, respectively 600 and $400 \mathrm{~km}$ westwards from Recife, in the State of Pernambuco, Brazil, revealed the presence of probable eclogites among the ore hosting mafics. At Bodocò the mafics are conformably enclosed by gneisses and migmatites of the Pajeú-Paraíba Foldbelt, $1.5 \mathrm{~km}$ southwards, from the tectonic contact with the Middle to Young Proterozoic Pianco-Alto B rígida Foldbelt. The gneissic sequence is supposed by some authors to be the northernmost exposure of the precursor of the São Francisco Craton in its Lower Proterozoic configuration. An early eclogitic assemblage of garnet + omphacite + rutile + zoisite is preserved in the mafics as relics, successively replaced by four retrograde parageneses, almost identical to those found in C type eclogites in the Italian Alps and Norway: 1. replacement of omphacite by clinopyroxene + placioclase and, later, ferro-glaucophane + plagioclase symplectites and of rutile by tijtanite and/or ilmenite; 2 . iron enrichment and recrystallization of the amphibole to crossite or magnesio-riebeckite; 3 . transformation of the mafics into, biotite, chlorite and epidote; 4. poiquiloblastic growth of plagioclase, forming banded amphibole-chlorite gneisses. The optical identification of the pyroxenes and amphiboles was confirmed by X-ray difractometry and is coherent with the textural relationship if isochemical reactions are assumed. At Floresta the metamafics are enclosed by Lower Proterozoic to Archean gneisses and migmatites or, as magaxenoliths, in $0.89 \mathrm{Ga}$ old granites, a few kilometers northwards from the Pernambuco Lineament. This lineament marks the northern limit of Pernambuco-Alagoas Massif, a supposed fragment of the precursor of the Sao Francisco Craton, with the Pajetf-Parafba Foldbelt. Of the supposed eclogitic assemblage only garnet and rutile are preserved in this case. Garnet crossitites identical to those found at Bodocò, and plagioclase + clinopyroxene symplectites in garnet amphibolites without individualized plagioclase grains, are supposed to have been formed by retrogressive metamorphism of eclogites. The symplectites recrystallize to coarse aggregates of normal hornblende and plagioclase, evolving gradually to banded garnet amphibolites.
\end{abstract}

Keywords: $C$ type eclogites, metamafics, Fe-Ti and Cr occurrences.

\begin{abstract}
RESUMO Estudos petrográficos em duas ocorrências de Ti em Bodocó e Floresta, respectivamente 600 e $400 \mathrm{~km}$ a oeste de Recife, Estado de Pernambuco, Brasil, revelaram a presença de prováveis eclogitos entre as rochas metamáfícas hospedeiras. Em Bodocó, as máficas são concordantemente encaixadas em gnaisses e migmatitos da Faixa de Dobramentos Paleo-Paraíba, 1,5 km ao sul do contato tectônico com a Faixa de Dobramentos Piancò-Alto Brfgida, do Proterozòico Médio a Superior. A seqüência gnáissica é suposta por alguns autores como sendo o extremo setentrional do precursor do Cráton do São Francisco na sua configuração proterozòica inferior. Uma paragênese precoce, eclogítica, composta por granada+onfacita+rutilo+zoisita, é preservada como relíquia, substituída sucessivamente por quatro paragêneses retrometamórficas, quase idênticas às observadas em eclogitos do tipo $C$ nos alpes italianos e Noruega: 1 . substituição de onfacita por uma simplectita de clinopiroxênio+plagioclásio evoluindo para outra de ferro-glaucofânio + plagioclásio, e de rutilo por ilmenita e/ou titanita; 2. enriquecimento em Fe e recristalizacão do anfibòlio para crossita ou magnésio-riebeckita; 3 . transformação dos minerais máfícos para biotita, clorita e epídoto; 4. crescimento poiquiloblástico do plagioclásio gerando gnaisses bandados. A identificação óptica dos piroxênios e anfibòlitos foi reforçada por resultados de difratometria de raios X e é coerente com as relações texturais, se assumidas reações isoquímicas na transformação de uma paragênese para a outra. Em Floresta, as metamáfícas são encaixadas por gnaisses e migmatitos do Arqueano ou Proterozóico Inferior ou, como megaencraves, em granites com $0,89 \mathrm{Ga}$, alguns $\mathrm{km}$ ao norte do Lineamento Pernambuco. Este lineamento marca o limite setentrional do Maciço PEAL, um suposto fragmento do precursor do Cráton de São Francisco com a Faixa de Dobramentos Pajeú-Paraíba. Da suposta paragênese eclogítica, neste caso, apenas a granada e rutilo foram preservados. Crossititos granatfferos, idênticos aos de Bodocò, e simplectitas de plagioclásio+clinopiroxênio em anfibòlitos granatfferos sem grãos de plagioclásio individualizados, são supostos produtos de retrometamorfísmo de eclogitos. As simplectitas recristalizam para agregados grossos de hornblenda normal e plagioclásio, evoluindo gradualmente para anfibòlitos granatíferos bandados.
\end{abstract}

Palavras-chaves: Eclogito tipo C, metamáfícas, ocorrências de Fe-Ti e Cr.

INTRODUÇÃO Decidiu-se divulgar os estudos petrográficos de duas ocorrências de provável eclogito no Estado de Pernambuco, embora análises químicas de minerais por microssonda, que permitiriam a determinação quantitativa das condições termobarométricas de sua formação, ainda estejam em andamento. Essa decisão foi motivada pela escassez de rochas dessa natureza no Brasil e por sua importância na interpretação geotectônica, já que normalmente se encontram em limites ativos de placas crustais.

Essas ocorrências situam-se próximas de limites entre grandes unidades geotectônicas (Fig. 1). Os dois afloramentos da ocorrência de Floresta ficam a poucos quilômetros a norte do Lineamento Pernambuco, que, segundo Brito-Neves (1975), delimita setentrionalmente o Maciço PernambucoAlagoas (PE/AL) - um suposto fragmento do precursor do Cráton do São Francisco - com a Faixa de Dobramentos Pajeú-Paraíba. Ainda segundo esse autor, a ocorrência de Bodocò está a $1,5 \mathrm{~km}$ a sudeste do limite tectônico (Mendes 1983) entre a Faixa de Dobramento Piancó-Alto Brígida (Grupo Salgueiro-Cachoeirinha), constituída por supracrustais metamorfizadas e dobradas no Proterozòico Superior (Brasiliano) com a Faixa de Dobramento Pajeú-Paraíba, do tipo vestigial, ou seja, dominantemente formada por rochas mais antigas, recicladas no Brasiliano. Segundo Santos \& Caldasso (1978), em

* Trabalho realizado com suporte financeiro do CNPq Proc. $n^{\circ}$ 405102-85/GL

** Departamento de Engenharia de Minas, UFPE, Av. Acadêmico Hélio Ramos s/ñ ${ }^{\circ}$ Cidade Universitária, CEP 50741, Recife, PE, Brasil 
cuja concepção o Lineamento Pernambuco em Floresta também coincidiria com o limite setentrional do PE/AL, a área de Bodocó corresponderia à extremidade setentrional do próprio Cráton do São Francisco em limite com o Grupo SalgueiroCachoeirinha (Faixa Piancó-Alto Erigida).

Em ambos os casos, as ocorrências de eclogito são parte de seqüências máfíco-ultramáficas portadoras de mineralizações de $\mathrm{Fe}-\mathrm{Ti}$, dobradas e metamorfizadas juntamente com as encaixantes gnáissico-migmatíticas.

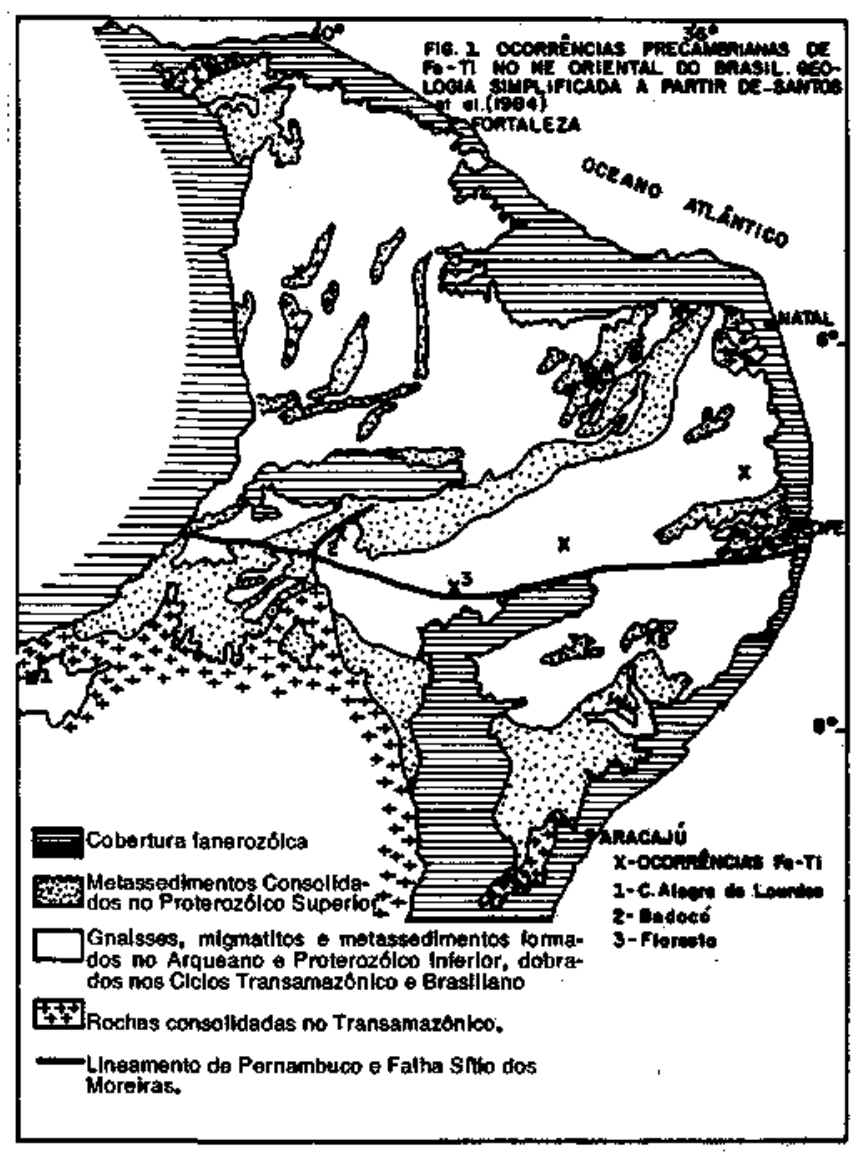

Figura I - Ocomencias pre-cambrianas de te-Ti no NE oriental do Brasil

Figure 1 - Precambrian Fe-Ti occurrences in NE Bradi

OCORRÊNCIA DE BODOCÓ GEOLOGIA LOCAL A ocorrência de minério de Fe-Ti no município de Bodocó (PE), cerca de $600 \mathrm{~km}$ a oeste do Recife, na Fazenda Boa Esperança, $27 \mathrm{~km}$ a leste da sede do município, foi citada pela primeira vez por Angel \& Riera (1959) como pequeno depósito de ilmenita com reservas da ordem de 100.0001 com $25 \%$ de $\mathrm{TiO}_{2}$. Em meados da década de 70, ao realizar um programa de pesquisa mineral, a Companhia de Pesquisa de Recursos Minerais (CPRM) identificou uma série de lentes máfico-ultramáficas intercaladas em uma seqüência de gnaisses e migmatitos do embasamento antigo como hospedeiras das mineralizações e, em uma das lentes, no Sítio Lagoa das Baraúnas, verificou a presença de níveis cromitíticos (Horikawa et al. 1979). As lentes mostram espessuras de algumas dezenas a mais de $100 \mathrm{~m}$ e têm extensão individual de até $2 \mathrm{~km}$, alinhando-se num trend $\mathrm{NE}$ ao longo de mais de $10 \mathrm{~km}, 1,5$ a $2 \mathrm{~km}$ a sudeste do contato tectônico do embasamento gnáissico-migmatítico encaixante, com os filitos e quartzitos do Grupo Salgueiro-Cachoeirinha (Fig. 2). Ainda segundo os mesmos autores, os clorititos, actinolititos, actínolita-clorita xistos, anfibolitos, anfibolitos granatíferos, metaperidotitos e gnaisses

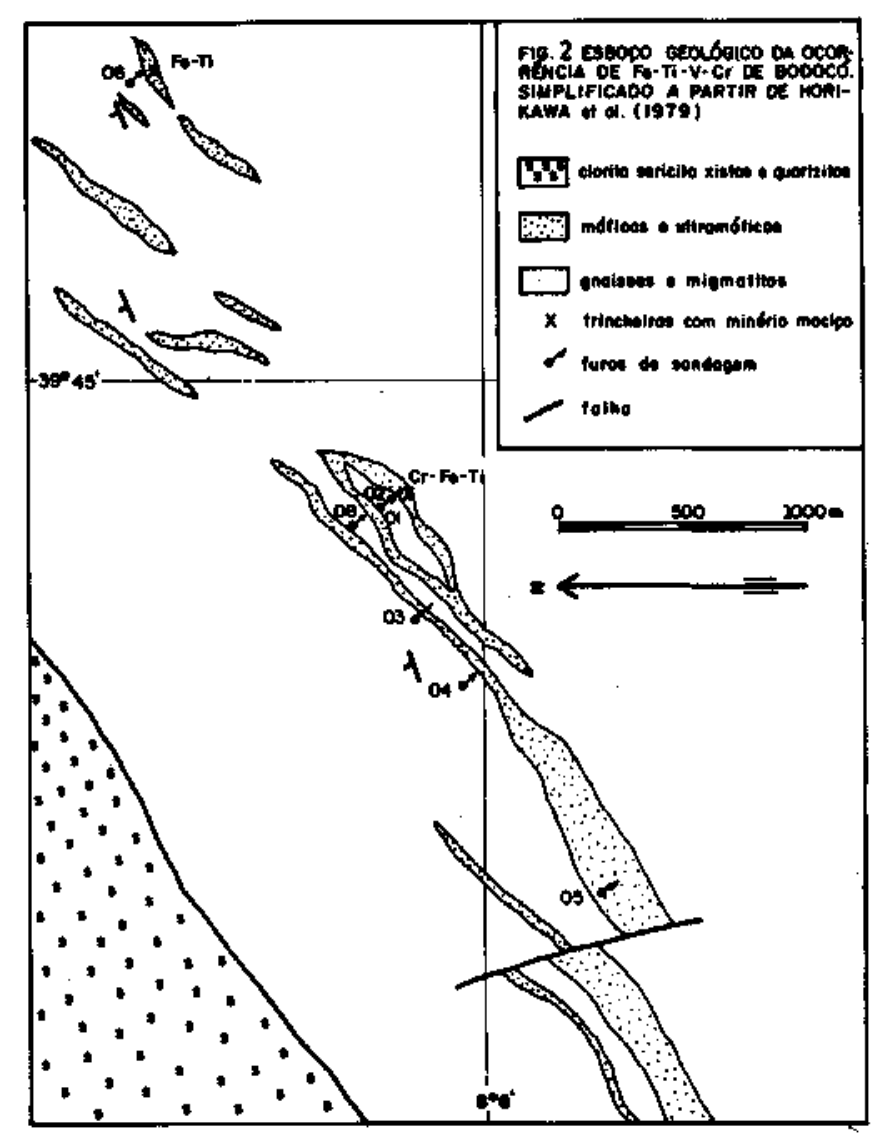

Figura 2 - Esboço geológico da ocorrência de $\mathrm{Fe}-\mathrm{Ti}-\mathrm{V}-\mathrm{Cr}$ de Bodocó. Simplificado a partir de Horikawa et ai. (1979) Figure 2 - Geological sketch of the Fe-Ti-V-Cr occurrences of Bodocó, simpkified from Horikawa et al. (1979)

dioríticos, que compõem as litologias das lentes, fariam parte de um complexo estratíficado, metamorfizado e dobrado conjuntamente com os gnaisses e migmatitos encaixantes em pelo menos duas fases de deformação. Não obstante Melo (1978, apud Horikawa et al., 1979), ao realizar os estudos petromicrográficos para o projeto da CPRM, tenha identificado em duas amostras o provável caráter eclogítico, com base na presença de anfibólio supostamente barroisítico, granada e rutilo em anfibolitos, essas rochas foram tratadas no relatório final do projeto da CPRM genericamente como anfibolitos granatíferos. Como argumento ti favor de uma origem como complexo estratíficado, os autores citam uma vez a própria variedade de litótipos e outra, a repetição até cinco vezes dos níveis cromitíticos considerados como relíquias de um layering magmático cíclico.

A redescrição detalhada dos furos de sondagem executados pela CPRM e arquivados na litoteca do 4- Distrito do Departamento Nacional da Produção Mineral (DNPM), no Recife, assim como das trincheiras ainda acessíveis, numa abordagem macroscópica permite distinguir basicamente quatro grupos de tipos litológicos como componentes das lentes máfico-ultramáficas: anfibolitos escuros, holomelanocráticos, de granulação fina; tremolititos com variáveis proporções de porfiroclastos de piroxênio, a piroxenitos; clorititos gradando para os dois tipos anteriores; e gnaisses anfibolíticos bandados com alternância milimétrica a centimétrica entre melanossomas dos três tipos anteriores e leucossoma rico em plagioclásio. Além desses tipos litológicos, ocorrem raras intercalações de minério maciço formado por óxidos de $\mathrm{Fe}-\mathrm{Ti}$ e $\mathrm{Cr}$-Ti-Fe-espiné- 
lios, mas que serão objeto de outro trabalho (Beurlen \& Lira no prelo).

Os contatos entre anfibolitos e tremolititos são, normalmente, mascarados por faixas de clorititos rigidamente foliados. Nos raros casos de contatos diretos observados apenas em testemunhos de sondagem, eles se apresentam quase sempre como superfícies simples, planas a levemente onduladas, paralelas à foliação comum, com mudança na cor e, menos brusca, na granulometria, às vezes sublinhadas por concentrações de opacos (sulfetos e/ou óxidos). Em apenas quatro casos foram observados contatos irregulares, lobulados, pelo menos localmente cortados pela foliação. Em três desses casos os tremolititos parecem penetrar ao longo de fraturas ou irregularidades dos anfibolitos e envolver pequenos "fragmentos" destes, sempre alongados e orientados paralelamente à foliação. No outro caso observa-se exatamente o contrário. A foliação das duas litologias é sempre paralela, mesmo quando corta o contato entre elas, mas é mais proeminente nos tremolititos. A aparente ambigüidade das relações de contato nos casos analisados, se interpretadas como relações primárias, poderia indicar um processo de mistura de magmas. No entanto, a complexidade da evolução estrutural, com pelo menos duas fases plicativas superpostas e diversos eventos cizalhantes, aliada à reduzida área passível de observação em testemunhos, não permite excluir a simulação dessas formas complexas de contato pela superposição de deformações mal compreendidas. Não obstante, é necessário ressaltar que essas observações foram efetuadas exatamente onde os efeitos de deformações dúcteis-rúpteis foram menos intensas (foliação menos intensa, ausência de milonitização e cloritização).

Já os contatos dos anfibolitos e tremolititos com os clorititos e com os gnaisses anfibolíticos são, por via de regra, gradativos, quando não tectônicos (neste caso marcados por intensa foliação trancando foliação anterior e, também, cloritização). Na passagem para os gnaisses anfibolíticos observa-se inicialmente o aparecimento de esparsas lâminas milimétricas de leucossoma nas rochas melanocráticas, tornando-se cada vez mais freqüentes e mais espessas. A gradação para os clorititos se dá com o aumento na proporção da clorita, muitas vezes acompanhada de biotita, substituindo os minerais ferromagnesianos.

Não se observa contato direto normal dos anfibolitos e tremolititos com os migmatitos félsicos regionais. A não ser nos contatos milonitizados, as litologias holomelanocráticas são sempre envolvidas por faixas de gnaisses anfibolíticos, formando, pois, um invólucro que, por sua vez, grada para os migmatitos regionais via aparecimento de neossomas alcalifeldspáticos e desaparecimento dos anfibólios e clorita etc. dos melanossomas a favor de uma freqüência maior da biotita.

Com exceção a essa "transição" dos corpos máficos, via gnaisses anfibolíticos bandados até os gnaisses e migmatitos regionais, tanto na base como no topo das lentes máficas, não é possível identificar nenhuma regularidade na distribuição dos litótipos que compõem os corpos. Embora se observe sempre uma alternância decimétrica a métrica, às vezes mesmo centimétrica entre os tipos litológicos, é completamente impossível qualquer correlação dos furos entre si e com as trincheiras na tentativa de estabelecer uma coluna litológica padrão ou mesmo ritmos de seqüências menores repetidos (Fig. 3). Até mesmo níveis mineralizados com espessuras decamétricas (caso de Poço Verde, ilmenomagnetitito maciço) ou litologias bem características como as brechas piroxeníticas em matriz tremolítica (tipo proeminente do grupo dos tremolititos) ou granada anfibolitos não são passíveis de correlação mesmo entre furos distanciados entre si de poucos decâmetros, o que contra-indica uma interpretação mesmo preliminar como complexo estratificado.

ESTUDOS PETROMICROGRÁFICOS O estudo de mais de 100 lâminas delgadas e polidas de amostras coletadas

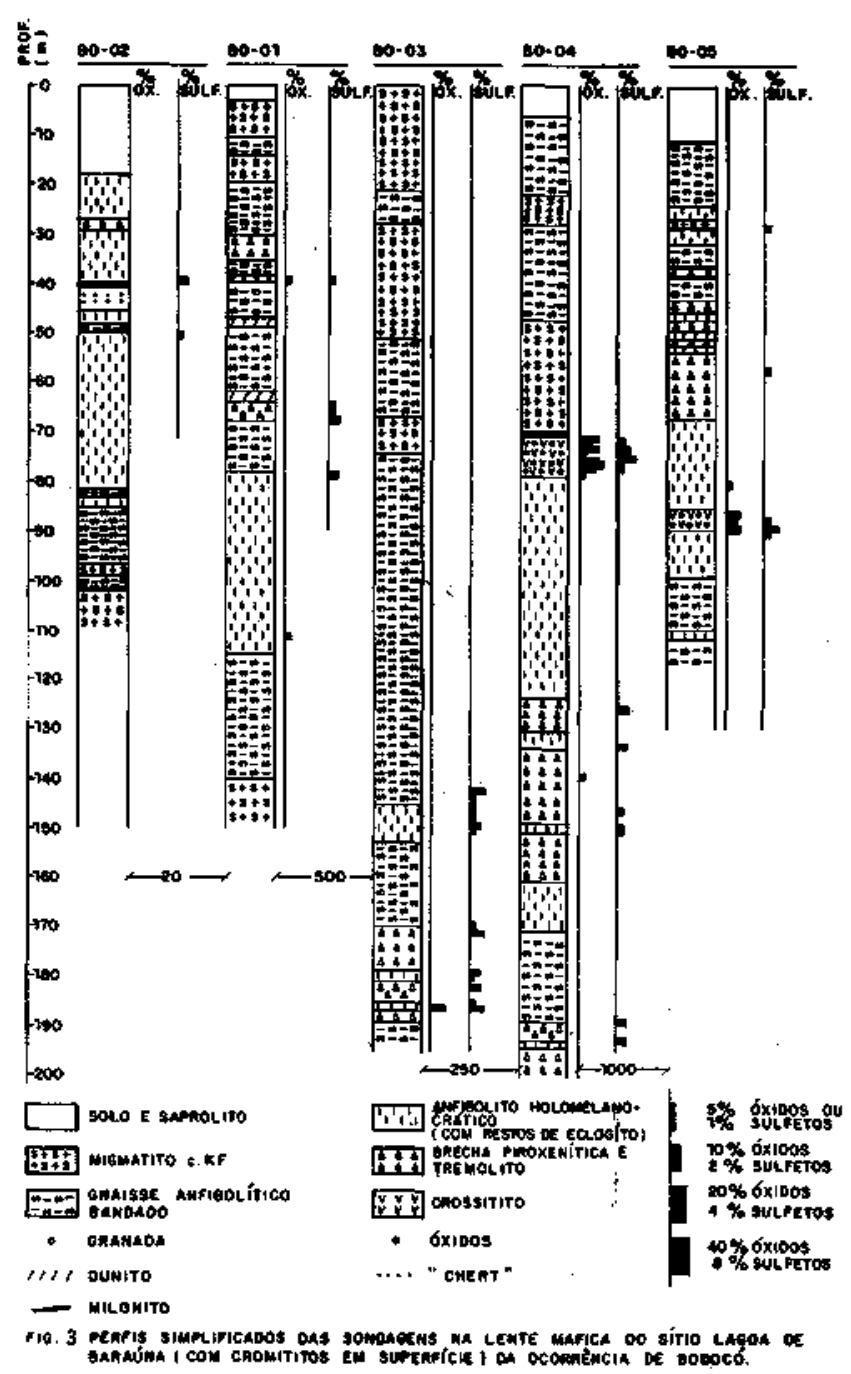

Figura 3-Perfis simplificados das sondagens na lente máfica do Sítio Lagoa Baraúna (com cromititos em superficie) da ocorrência de Bodocó

Figure 3 - Simplified profiles of the bore holes of the Lagoa de Baraúna mafic lense (with chromitite outcrops) of the Bodocó occurrence

sistematicamente nos furos de sondagens e trincheiras, de modo a cobrir todos os tipos litológicos e, principalmente, seus contatos, permitiu estabelecer preliminarmente que: i. os clorititos são produto do retrometamorfismo das rochas, tanto do grupo dos anfibolitos holomelanocráticos como dos tremolititos com porfiroclastos de piroxênio. Essa afirmativa se fundamenta na observação de que a clorita substitui perifericamente todos os minerais ferromagnesianos daquelas rochas, muitas vezes juntamente com carbonato e/ou epídoto e/ou biotita e de que essa substituição é mais intensa ou completa à medida que aumenta a foliação das rochas, dada pela própria orientação da clorita e pela laminação composicional; ii. os gnaisses anfibolíticos bandados se formaram por recristalização e/ou migmatização, tanto dos anfibolitos, como dos tremolititos já cloritizados, ou seja, posteriormente ao retrometamorfismo que gerou os clorititos. Esse fato se baseia na observação de que o plagioclásio dos leucossomas inclui poiquiloblasticamente restos rigidamente orientados segundo a foliação dos melanossomas, de todos os minerais dos anfibolitos, tremolititos e clorititos, que constituem os próprios melanossomas (Fig. 4A e B). Posto pois, como premissa, que clorititos e gnaisses anfibolíticos são produtos de fases tectonometa- 

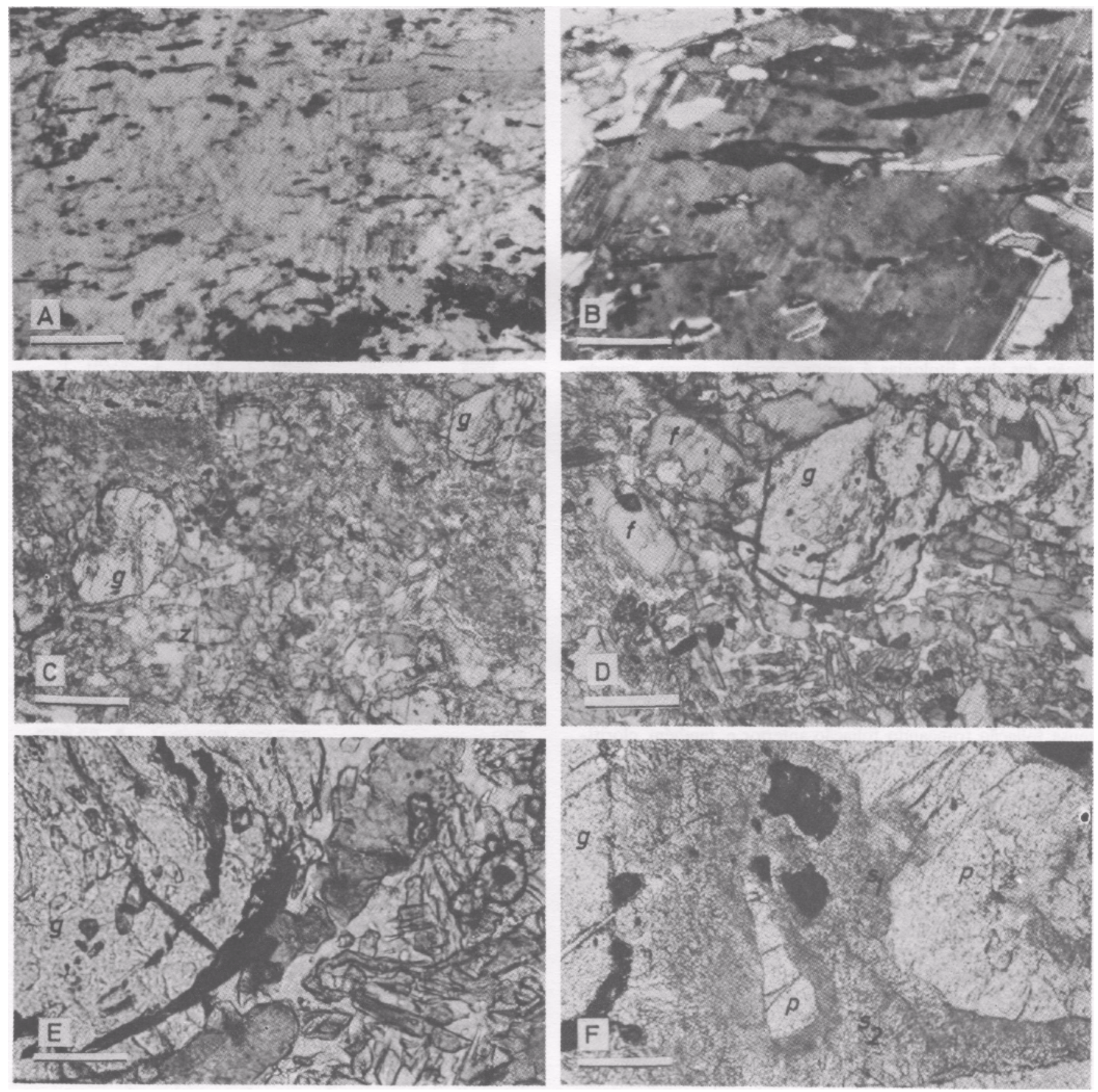

Figura 4 - Fotomicrografias de eclogitos e produtos retrometamórficos da ocorrência de Lagoa de Baraúna, Bodocó: A. gnaisse anfibolítico bandado com estreita faixa de melanossoma na parte inferior da foto, formada por $F$ e-glaucofânio, clorita, biotita epidoto, rutilo e ilmenita e leucossoma formado por plagioclásio grosso com inclusões orientadas dos minerais do melanossoma. Nic. II, barra = 0,7 mm; B. detalhe do canto superior esquerdo mostrando as inclusões orientadas em um grão grosso de plagioclásio. Nic. X, barra $=0,3 \mathrm{~mm}$. C, D e E. anfibolito zoisita-granatifero com matriz formada por simplectita de ferro-glaucofânio e plagioclásio, pseudomórfica segundo onfacita e alguns blastos prismáticos de zoisita (z) e porfiroblastos de granada (g), perifericamente substituidos por f erro-glaucofânio mais grossa (f). Observar o fraturamento vertical, transversal afoliação, atingindo apenas a granada e zoisita, precoce em Delação à simplectita, portanto, e as inclusões helicíticas de rutilo acicular (quase preto) e zoisita na granada; E. a coroa de titanita envolvendo resto de rutilo na matriz. Nic.ll, barra emA = 0,7 mm, B= $0,3 \mathrm{~mm} e C=0,11 \mathrm{~mm}$. F. relictos de onfacita (p) em matriz simplectítica de clinopiroxênio e plagioclásio (Si) envolvendo diretamente a onfacita, gradando para uma simplectita mais grossa de ferro-glaucofânio + plagiociásio (S2). Observar novamente o fraturamento atingindo os restos de onfacita e de granada aproveitado para a formação da simplectita. Os grãos quase opacos são de rutilo, originalmente incluso na onfacita. Nic. II, barra $=0,3 \mathrm{~mm}$

Figure 4 - Photomicrographs of ecogites and its retrograde metamorphic products of the Lagoa da Baraúna occurrence, Bodocó: A.banded amphibolitic gneise with a thin melanossome band in the lower part of photo, formed by ferro-glaucophane, chlorite, biotite, epidote, rutile and ilmenite and die leucossome formed by coarse plagioclase grains including oriented relics of the minerals of the melanossome. $/ /$ nicols, bar $=0.7 \mathrm{~mm}$; B. detail of the upper left part of picture A., shwing the oriented inclusions of mafic minerals in the plagioclase. X nicols, Bar = 0.3 mm; C, D and E. zoisite-garnet-amphibolite with a symplectitic matrix of ferro-glaucophane and plagioclasse, formed by the break down of omphacites. SOme coarse zoisite $(\mathrm{z})$ and garnet (g) porphyroblasts, partially replaced by coarser ferro-glaucophane, are observed. Fractures in ringht angle to the foliation glaucophane, are observed only in the porphyroblasts and not in the matrix minerals and are older than the Fractures in ringht angle to the foliation nelicitic acicular rutile inclusions in the garnet and in $\mathrm{E}$ the titanite rim surrounding and replacing rutile. $/ /$ nicols, bar in $\mathrm{C}=0.7 \mathrm{~mm}$, in $\mathrm{D}=0.3 \mathrm{~mm}$ nelicitic acicular rutile inclusions in the garnet and in E the titanite rim surrounding and replacing rutile. I/ nicols, bar in $C=0.7 \mathrm{~mm}, 1 \mathrm{in} D=0.3 \mathrm{~mm}$ a coarser symplectite of ferro-glaucophane + plagioclase ( $\mathrm{S} 2$ ). Again the intensive fracture system (NE) is restricted to the blastic grains. The dark inclusions in the omphacite are rutile. // nicols, bar $=0.3 \mathrm{~mm}$ 
mórficas distintas e tardias em relação à fase de formação dos anfibolitos e tremolititos e que estes últimos incluem os litotipos supostamente eclogíticos, objeto do presente trabalho, passa-se a seguir a uma descrição detalhada apenas desses dois grupos de rochas.

Anfibolitos holomelanocráticos Neste grupo de rochas foram observados os seguintes componentes mineralógicos: anfibólios verdes, granada, zoisita e/ou clinozoisita-epídoto, como minerais essenciais mais freqüentes, plagioclásio, clinopiroxênio e quartzo como essenciais ocasionais, rutilo, ilmenita, titanita, apatita, allanita, zircão, sulfetos e mica branca como acessórios. Clorita e/ou biotita e carbonates, além dos óxidos de $\mathrm{Fe}-\mathrm{Ti}-\mathrm{Cr}$, ocorrem em proporções muito variáveis, podendo ocasionalmente formar como constituintes principais, com gradação para o grupo dos clorititos, veios de carbonato ou intercalações de minério maciço, milimétricas e decimétricas.

As rochas do grupo têm uma granulação fina, de $0,5 \mathrm{~mm}$ em média, e mostram uma foliação apenas incipiente, com coloração variável de verde-escuro a verde-acinzentado ou cinza-esverdeado. Macroscopicamente, só é possível identificar o anfibólio e, quando ocorre em proporções maiores, a granada, a clorita e a biotita. De acordo com as variações nas composições modais poderiam ser distinguidos os seguintes tipos litológicos dentro do grupo: anfibolitos monominerálicos, clorita e/ou biotita-anfibolitos e eclogitos mais ou menos retrometamorfizados incluindo: anfibolitos granatíferos (até $50 \%$ de granada), anfibolitos zoisita-granatíferos, anfibolitos piroxênio-granatíferos, todos de granulação fina, quase afanítica, e crossititos, granatíferos ou não, de granulação média a grossa. Como, no entanto, há sempre uma gradação entre eles sem variação brusca nas características ópticas dos minerais componentes ou da composição modal, essa distinção a priori não parece necessária, passando-se a seguir à descrição dos minerais e seus intercrescimentos.

Distinguem-se dois tipos de anfibólios no grupo. O primeiro, mais claro e de granulação fina, mais freqüente, apresenta sempre um pleocroísmo de verde-amarelado-claro a quase incolor e verde-azulado ou cinza-azulado, extinção máxima $\mathrm{Y} / \mathrm{c}$ entre $15^{\circ}$ e $18^{\circ}, 2 \mathrm{~V}_{\mathrm{X}}$ da ordem de $70^{\circ}$, e com base nessas características, foi dagnosticado por Mello apud Horikawa et al. (1979) como do tipo barroisítico. O difratograma de raios $X$ indica tratar-se de ferro-glaucofânio. Ocorre em hábito hipidiomórfico, prismático, frouxamente orientado (partes mais maciças com dominância de anfibólio) a bem orientado nas partes mais laminadas ou foliadas, quando é freqüentemente zonado, mostrando uma coloração mais intensa e extinção maior na borda (de $18^{\circ}$ a $20^{\circ}$ ). Nas faixas mais granatíferas, esses mesmo anfibólio, adicionalmente à forma acima descrita, ocorre formando uma simplectita com plagioclásio com granulometria da ordem de 20 a 100 micra, com coloração e extinção iguais aos núcleos da forma anteriormente descrita. Esses agregados simplectíticos formam zonas maiores em que os granules mantêm a mesma posição de extinção. Essas zonas, por sua vez, formam um mosaico poligonal com granulometria da ordem de $1 \mathrm{~mm}$, tudo indicando tratar-se de pseudomorfoses segundo piroxênio onfacítico, conforme descrevem Troeger (1967), Winkler (1965), Krogh (1980), entre inúmeros outros autores, com produto típico do retrometamorfismo de eclogitos.

O outro anfibólio, verde-azulado-escuro com granulometria mais grossa de até $10 \mathrm{~mm}$, apresenta pleocroísmo de verde-amarelado-claro a verde-esmeralda a azul-turquesa intenso, quase opaco, extinção máxima $\mathrm{X} / \mathrm{c}$ de $18^{\circ}$ a $20^{\circ}, 2 \mathrm{Vx}$ próximo a $80^{\circ}-90^{\circ}$, características próximas da crossita ferrífera ou riebeckita. $\mathrm{O}$ difratograma de raios $\mathrm{X}$ indica tratar-se de magnésio-riebeckita. Ocorre sempre formando a matriz de zonas mineralizadas em ilmenita-magnetita, ou alternando com elas, freqüentemente com granada associada à qual substitui nitidamente, a partir da periferia dos grãos ou das fraturas, formando os crossititos granitífero ou crossititos puros.

Tudo indica que tanto a crossita como o ferro-glaucofânio, quando em grãos maiores e não simplectiticamente intercrescida com plagioclásio, são também produtos do retrometamorfismo, agora mais avançado pela recristalização da simplectita e reação com os minerais mais ferrosos como granada e zoisita-epídoto.

A granada, da série almandina/piropo conforme dados difratométricos de raios $X$, forma idioblastos de até $3 \mathrm{~mm}$ (muito localmente até $1 \mathrm{~cm}$ ) e contêm inclusões de zoisita, rutilo, anfibólio idiomórfico (mesmo pleocroísmo e extinção do ferro-glaucofânio) e plagioclásio como únicas fases determinadas com segurança. Algumas vezes as inclusões de rutilo e zoisita se alinham segundo texturas helicíticas (snow ball, (Fig. $4 \mathrm{C}$ a E) que atestam o caráter precoce das inclusões e o caráter blástico da granada, pelo menos em parte formada por metamorfismo progressivo em rocha já bem foliada, e não diretamente a partir de rochas granulares, do manto. Ainda ocorrem inclusões de titanita, epídoto, quartzo, além de outras não identificadas (até fluidas, polifásicas), mas que, devido ao, por via de regra, intenso fraturamento da granada, formas muitas vezes côncavas e não identificação em texturas helicíticas, devem ser formações tardias por substituição da granada e/ou de plagioclásio + ferro-glaucofânio. Muitas vezes, entre essa simplectita e os restos de onfacita observa-se uma faixa de simplectita ainda mais fina, submicroscópica formada por plagioclásio e outro clinopiroxênio, provavelmente diopsídio, com posição de extinção um pouco ondulante, aproximadamente igual à dos relictos. Com a distância do bordo da onfacita, a granulometria da simplectita aumenta gradualmente e o lugar do clinopiroxênio passa a ser ocupado pelo ferro-glaucofânio (Fig. 5A a C). Nesses casos, corroborando a natureza retrometamórfica dessas simplectitas, genericamente observadas no grupo dos anfibolitos granatíferos, o caráter eclogítico do grupo fica petrograficamente fundamentado com real segurança.

O quartzo ocorre como mineral essencial restrito a algumas bandas, centimétricas a decimétricas, sob forma de mosaico microgranular, formando a matriz de relictos de granada, rutilo e ferroglaucofana, em proporções variadas. Normalmente, essas faixas quartzosas incluem também lâminas milimétricas enriquecidas em biotita, titanita e clorita, muito rigidamente orientadas. Trata-se tipicamente de um produto de formação tardia em relação a todos esses minerais que enolve e substitui parcialmente. Parece que sua formação está ligada a uma fase de intensa deformação.

A biotita e a clorita ocorrem como acessórios em todas as rochas do grupo substituindo perifericamente granada, anfibólio e zoisita. Em zonas mais foliadas, freqüentemente coincidindo com contatos litológicos, ou em níveis mais máficos a proporção desses minerais aumenta bastante e gradativamente em detrimento dos minerais que substituem, mantendo, geralmente, pequenos restos como inclusões, gradando assim para os clorititos monominerálicos. A clorita é da variedade ctinocloro, confirmada por difratometria de raios X, e a biotita do tipo titanífera, indicada pelos tons vermelhos de pleocroísmo.

$\mathrm{O}$ rutilo é o acessório mais freqüentemente observado, ocorrendo como inclusões em todos os outros minerais das rochas do grupo, até nos relictos de omphacita, e também formando rosários de grãos alongados alinhados paralelamente à foliação das rochas (Fig. 5A a Q. Quase por via de regra, o rutilo é envolvido por uma estreita coroa de titanita ou, mais raramente, de ilmenita, por sua vez envolvida por titanita (Fig. $5 \mathrm{D}$ e E). Em várias lâminas observaram-se teores de rutilo da ordem de $5 \%$ a $10 \%$. Outros acessórios que localmente podem formar concentrações maiores em vênulos e schlieren normalmente paralelos à foliação di rocha são carbonato e sulfetos (pirrotita, pirita, pentlandita, calcopirita e millerita).

Como acessório freqüente, encontrado em todos os tipos 

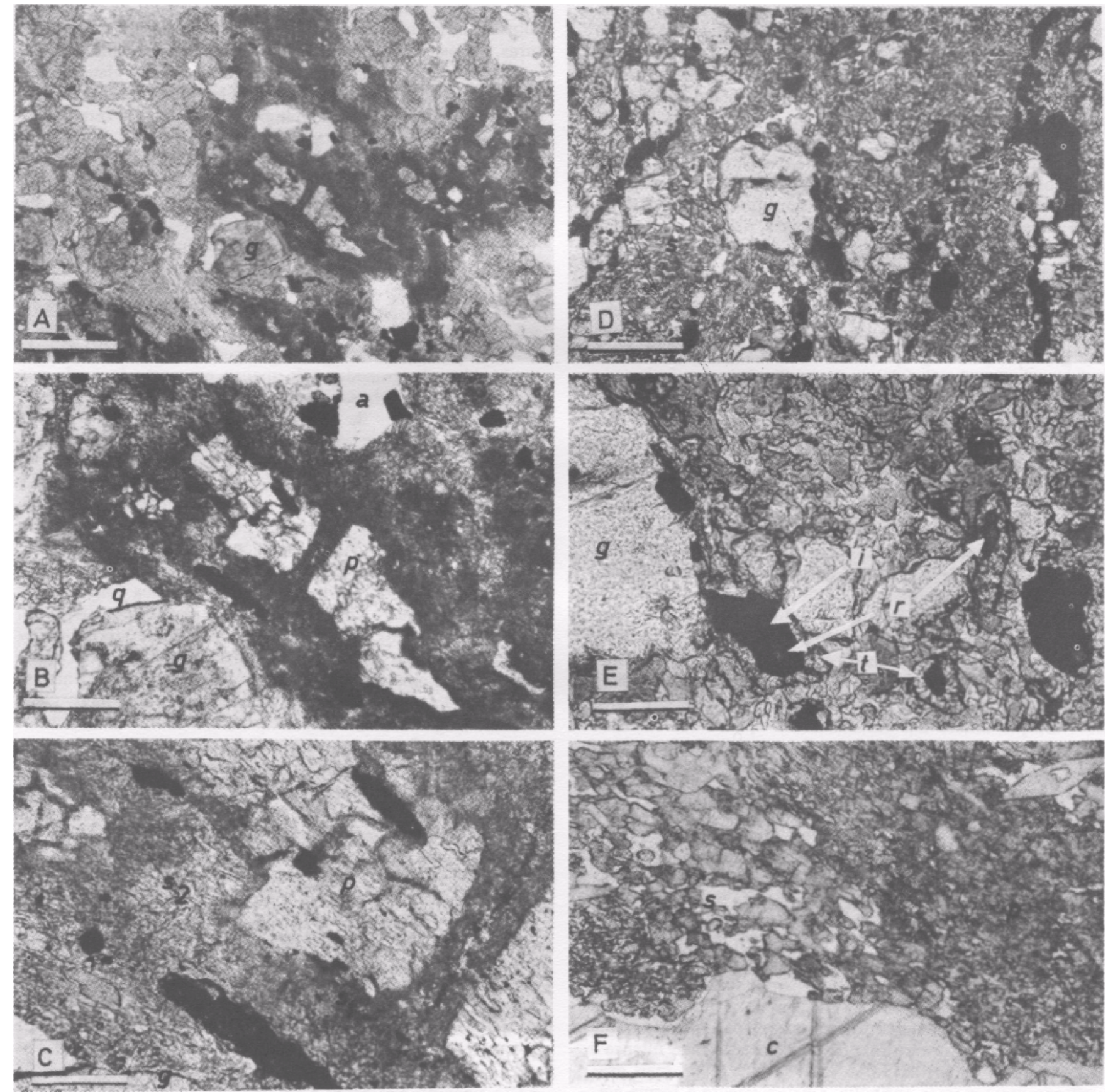

Figura 5 - Fotomicrografias de eclogitos e produtos retrometamórficos da ocorrência de Lagoa de Baraúna, Bodocó: A, B e C. anfibolitos granatíferos com restos de onfacita e porfiroblastos de granada em matriz simplectítica de diopsídio + plagioclásio (SI) penetrando nas fraturas e circundando diretamente a onfacita (p), recristalizando para simplectita mais grossa deferro-glaucofânio + plagioclásio (S2). Tanto na matriz como na onfacita observam-se inclusões alongadas de rutilo (quase preto) orientadas segundo o prisma do piroxênio. Mais uma vez observa-se o fraturamento comum à onfacita e granada (g) ausente na matriz. Observam-se ainda restos de apatita (a) e quartzo intersticial (q), incolores. Nic. II, barra em $A=0,7 \mathrm{~mm}, B-0,3 \mathrm{~mm}$ e $C=0,11 \mathrm{~mm}$; D e E. rosários de rutilo ( $r$, quase preto) em anfibolito granatifero $(g)$ em matriz simplectítica deferro-glaucofânio + plagioclásio. $O$ rutilo é envolvido por ilmenita (i) que por sua vez é envolvida por titanita (t), Nic. //, barra em D-0,7 mm e E = 0,3 mm. F. tremolitito com restos de porfiroclastos de piroxênio onfacítico (p) substituídos perifericamente por simplectita de clinopiroxênio + plagioclásio. Tanto a simplectita como a onfacita diretamente podem ser parcialmente substituidos por calcita (c) ou tremolita (t). Nic. II, bar$\mathrm{ra}-0,3 \mathrm{~mm}$

Figure 5 - Photomicrographs of eclogites and its retrograde metamorfic products from Lagoa da Baraúna, Bodocó: A, B and C. amphibolites with omphacite relics and garnet porphyroblasts in a symplectitic matrix of diopside + plagioclase ( $\mathrm{Si}$ ) surrounding and replacing the omphacite along the fractures. The S1 symplectite recrystallizes toa a coarser ferro-glaucophane + plagioclase symplectite (S2). Inclusions of rutile (r) in the omphacite are oriented along (110) and are preserved with the same direction in the synplectitic matrix. Again the NE oriented fractures are restricted to the garnet (g) and omphacite (P) grains lacking in the matrix. Some relics of apatite (a) and interstitial quartz (q) are also present. // nicols, bar in $\mathrm{A}=0.7 \mathrm{~mm}$, in $\mathrm{B}=$ $0.3 \mathrm{~mm}$ and $\mathrm{C}=0.11 \mathrm{~mm} ; \mathrm{D}$ and $\mathrm{E}$. rutite (r) strings in garnet $(\mathrm{g})$ rich amphibolite with a symplectite matrix of ferro-glaucophane + plagioclase. The rutile is enveloped by ilmenite (i) and titanite ( $\mathrm{t}$. $/ /$ nicols, bar in $\mathrm{D}=0.7 \mathrm{~mm}$ and $\mathrm{E}=0.3 \mathrm{~mm}$; F. tremolitite with relics on supposedly imphacitic pyroxene (p) replaced by a symplectitic rim of diopside + plagioclase. Both, the omphacite and the symplectite are replaced by calcite (c) and/or tremolite $(\mathrm{t}) . / /$ nicols, bar $=0.3 \mathrm{~mm}$ 
litológicos do grupo, mas sempre em pequenas proporções, ocorre a apatita como inclusões nos minerais essenciais ou como grãos arredondados individualizados de até $0,3 \mathrm{~mm}$. Neste último caso observa-se o mesmo fraturamento transversal à foliação já descrito para a granada, indicando tratar-se de uma fase bastante precoce, provavelmente relíquia da rocha ígnea original. Acessórios menos comuns são o zircão e allanita, em minúsculas inclusões nos minerais essenciais, que não permitem deduções sobre sua formação.

Tremolitítos com porfiroclastos de clinopiroxênio Neste grupo observa-se como minerais essenciais comuns o clinopiroxênio e a tremolita e, ocasionalmente, a clorita, o carbonato e, raramente, a olivina. Subordinadamente podem ocorrer quartzo, plagioclásio opacos e, mais raramente, granada. De acordo com as variações na composição modal podem ser identificados de piroxenitos quase monominerálicos, com matriz tremolítica subordinada, a brechas piroxeníticas com matriz tremolítica foliada, a tremolitítos foliados como rochas comuns do grupo. Apenas raramente foram observadas intercalações pouco expressivas de dunitos e peridotitos, serpentinizados, com restos de olivina preservada. $\mathrm{Na}$ lente máfica mais setentrional, observa-se associada a esse grupo de litótipos uma mineralização expressiva, com espessura decamétrica de ilmenomagnetititos maciços a disseminados, com trama primária magmática preservada, mostrando cumulates de piroxênio, com até $10 \mathrm{~mm}$ de tamanho em matriz de opacos (network ore).

O piroxênio é por via de regra um clinopiroxênio incolor ao microscópio. Distinguem-se dois tipos quanto à textura. $\mathrm{O}$ primeiro é quase sempre muito rico em finíssimas inclusões de ilmenita e/ou rutilo e magnetita lamelares (schillerização) orientadas segundo o prisma, responsáveis pela coloração cinzenta a olho desarmado e pelo aspecto às vezes quase opaco ao microscópio. Ocasionalmente observa-se ainda inclusões de sulfetos, granada amarelo-oliva (uvarovita ?) e inclusões fluidas polifásicas. Ocorre, por via de regra, em grãos grossos de vários milímetros a $5 \mathrm{~cm}$ de tamanho. Apresenta $2 \mathrm{Vx}$ aproximado de $60^{\circ}$. Nos litótipos mais pobres em tremolita e/ou clorita observa-se a forma original poligonal dos grãos em textura próxima a favo de mel grosso com substituição apenas incipiente e periférica pelos outros minerais. Na borda desse piroxênio, indicando tratar-se de onfacita, observa-se ocasionalmente uma simplectita de clinopiroxênio límpido e/ou tremolita com plagioclásio (Figs. 5F, 7 A e B), suposição reforçada pelos resultados de difratometria de raios $\mathrm{X}$

$\mathrm{O}$ segundo tipo de clinopiroxênio ocorre em grãos menores, hipidiomórficos com tendência a formas tabulares, $2 \mathrm{Vx}$ de $50^{\circ}$ a $60^{\circ}$, límpido e pobre em inclusões e é, provavelmente, diopsídio comum. Às vezes é observado com crescimento homoaxial e periférico em relação à onfacita, provavelmente resultando da recristalização do piroxênio da simplectita já descrita, mostrando uma gradual reorientação à medida que se afasta da onfacita, agora segundo a foliação da matriz. Esse tipo de piroxênio não se mostra tão claramente substituído pela tremolita, mas, sim, intercrescido com ela em formas simples retilíneas, indicando equilíbrio com a mesma. Pode ser substituído por clorita e/ou carbonato.

A tremolita parece ter-se formado a partir da onfacita, principalmente podendo substituí-la quase integralmente, formando um mosaico pouco orientado. Nos tipos litológicos mais foliados a tremolita tende a se reorientar segundo a foliação da rocha, que passa a contornar eventuais restos de onfacitas, poligonais irregulares, brecháticos a facoidais, menos intensamente substituídos. A tremolita por sua vez é freqüentemente substituída por clorita e/ou carbonato. Podem assim ser encontrados todos os tipos litológicos intermediários entre piroxenitos quase monominerálicos a brechas piroxeníticas com matriz de tremolita-clorita foliada, tremolititos foliados, clorita-tremolita xistos foliados ou clorititos carbonáticos.
A clorita é quase completamente incolor ao microscópio, e ainda da espécie clinocloro conforme a difratometria, tendo sido determinada a "leuchtenbergita" apenas nos níveis cromitíticos e na banda de dunito mencionada acima. Ocorre substituindo todos os minerais ferromagnesianos do grupo, geralmente com carbonato e quartzo associados. Sua formação é mais intensa nas porções mais foliadas, estando ela, em geral, rigidamente orientada. O quartzo e o carbonato são, normalmente, intersticiais em relação aos outros minerais, mesmo à clorita. Da mesma forma os opacos, tanto sulfetos como óxidos, são normalmente intersticiais, amoldando-se às formas dos piroxênios e da tremolita, indicando uma recristalização durante o metamorfismo progressivo, mas são indiomórficos em relação à clorita, quartzo e carbonato.

De acordo com todas essas observações petrográficas pode-se estabelecer a sucessão mineral conforme o quadro 1.

Quadro 1 - Sucessão mineral dos tremolititos e anfibolitos de Bodocó

Plate 1 - Para genetic of the tremolitítes and amphibolites of Bodocó

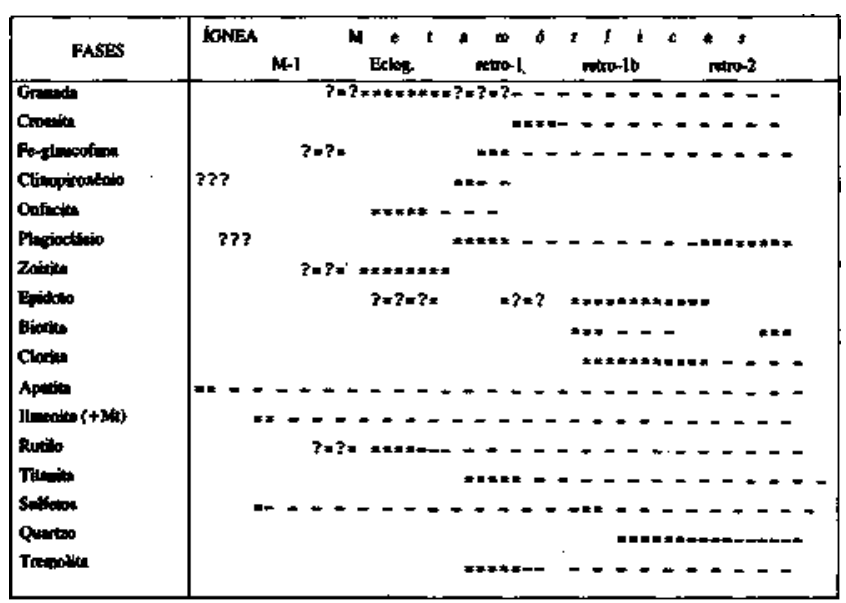

(M-1 e retro Ia: Fácies glaucofânio xisto; retro 1b: fácies xisto verde $;==$ principal fase de formação; $=?=$ formação suposta; ----- relíquias preservadas).

OCORRÊNCIA DE FLORESTA GEOLOGIA LO$C A L$ Em recente trabalho realizado pelo Radambrasil para a Minérios de Pernambuco S.A., Veronese et al. (1985) distinguiram quatro grupos de mineralizações ferrotitanadas (Fig. 6). Já a análise bibliográfica chamou a atenção sobre a freqüência com que ocorrem anfibolitos, metanortositos e metagabros granatíferos como componentes das seqüências hospedeiras, ao lado de tremolita-actinolita-clorita xistos dominantes e metaperidotitos subordinados (Veronese et al. 1985).

O recadastramento das ocorrências do Serrote das Pedras Pretas, Riacho da Posse, Barragem, Gavião e Aeroporto permitiu a confirmação dos litótipos granatíferos e, em Barragem e Riacho da Posse, a presença de rochas compostas exclusivamente por granada e anfibólio, sem plagioclásio, levando à suspeita sobre a natureza possivelmente eclogítica.

O depósito de Riacho da Posse, atualmente responsável por $80 \%$ das reservas de $25 \mathrm{M} \mathrm{t}$, estimadas por Veronese et al. (1985) para o distrito, fica situado a $12,6 \mathrm{~km}$ a $\mathrm{N}$ da cidade de Floresta pela estrada para Carnaubeira, a 1,2 km a leste da referida estrada. $\mathrm{O}$ corpo mineralizado é identificado em superfície apenas pelo solo avermelhado e blocos soltos de rochas básicas e minério numa área elíptica com alongamento EW e com eixos medindo aproximadamente 600 por $200 \mathrm{~m}$. Forma e dimensões do corpo foram confirmados por geofísica e dois furos de sondagem durante o projeto (Silva et al. 1984). O corpo está completamente envolvido por um granito gnais- 


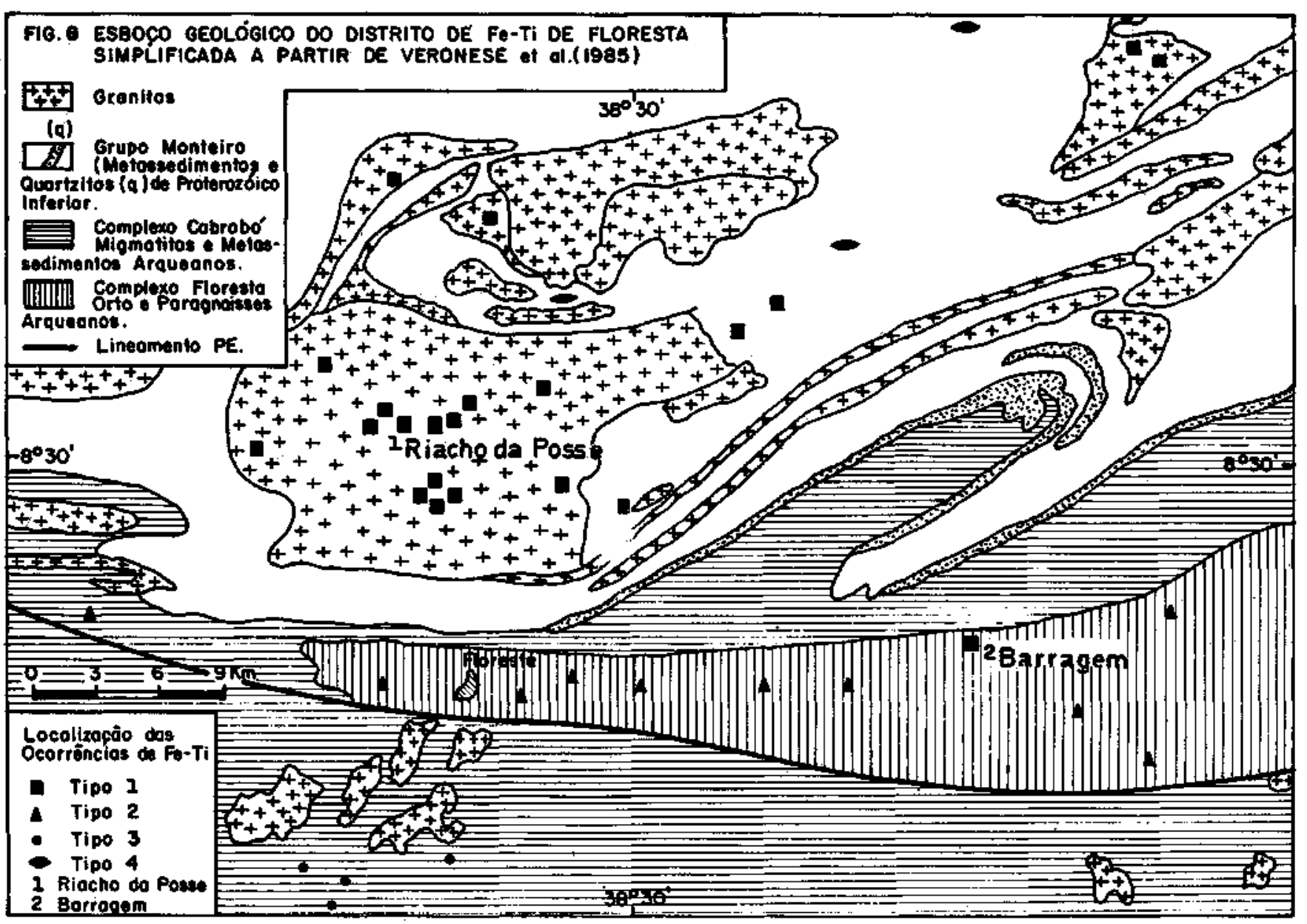

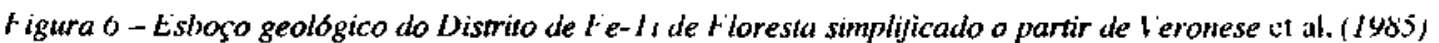

Figure 6-Geological sketch of the Fe-Ti district of Floresta, simplified after Veronede ef aL,(1985)

sificado porfirítico, datado de $890 \mathrm{Ma}$, e foi por isso interpretado como megaenclave por Veronese et al. (1985). O granito em questão é intrusivo nos metassedimentos do Grupo Monteiro. Enquanto a foliação do granito mergulha suavemente para $\mathrm{NW}$, os dados geoffsicos indicam um mergulho suave para SE do corpo mineralizado. A reanálise dos furos de sondagem RP-05 e RP-06, já referidos, permitiu identificar dois níveis contínuos e correlacionáveis de granada crossititos, intercalados em tremolita xistos e metadunitos mineralizados (network ore ilmenomagnetítico em cumulados de olivina serpentinizados com sulfetos intersticiais)

A ocorrência de Barragem, a $26 \mathrm{~km}$ a E de Floresta pela BR-360, a $1 \mathrm{~km}$ a $\mathrm{N}$ dessa estrada, novamente forma uma mancha de solo escuro com blocos soltos de metabasitos e minério ilmenítico maciço, com raríssimos afloramentos indicando, de acordo com Veronese et al. (1985), a alternância das lentes metabásicas com gnaisses e quartzitos encaixantes num núcleo sinformal com extensão total de 3 por $0,6 \mathrm{~km}$ e espessura máxima de cada lente da ordem de $200 \mathrm{~m}$. As litologias existentes, identificadas em sua maioria pelos blocos soltos, indicam a presença de tremolita-actinolita-clorita xistos, homblenditos granatíferos, metagabros e metanortositos granadíferos, metaperidotitos, metadioritos, ilmenititos maciços e nódulos de espinélio. A idade arqueana das metabásicas, duplamente fundamentada, é dada por determinação isolada de $\mathrm{K} / \mathrm{Ar}$ em metanortosito (2, $85 \mathrm{Ga}$ ) e isócrona de $\mathrm{Rb} / \mathrm{Sr}$ em rocha total (com três pontos dando $2,7 \mathrm{Ga}$ e outro, isolado, com $3,4 \mathrm{Ga}$ ) nos gnaisses encaixantes.
PETROGRAFIA Na ocorrência de Riacho da Posse, os crossititos granatíferos mencionados acima são o único tipo litológico provavelmente eclogítico. Podem conter até $70 \%$ modais de granada em grãos arredondados numa matriz de anfibólio, com granulometria de poucos a mais de $20 \mathrm{~mm}$. O anfibólio é ligeiramente orientado, com pleocroísmo de amarelo-esverdeado-claro a verde-esmeralda a azul-esverdeado intenso, quase opaco, ângulo de extinção de $18^{\circ}, 2 \mathrm{Vx}$ maior que $70^{\circ}$ e cujo difratograma de raios $\mathrm{X}$ indicou tratar-se de crossita. $\mathrm{O}$ anfibólio e também a granada são freqüentemente substituídos por biotita titanífera, normalmente bem orientada, em processo que culmina na formação de faixas de biotita xisto intercaladas, preferencialmente próximo aos contatos com as ultramáficas mineralizadas. A granada apresenta sempre um fraturamento intenso, orientado normalmente à foliação e bandamento da rocha e que quase não atinge o anfibólio da matriz, completamente ausente nas faixas biotíticas (Fig. 7C). Como inclusões na granada, observaram-se prismas idiomórficos de anfibólio com coloração menos intensa que a crossita, de amarelo-esverdeado quase incolor a verde-azulado-acinzentado-claro, provavelmente ferro-glaucofânio, além de alguns grãos de rutüo e outras inclusões não identificáveis. A granada é substituída pela crossita a partir das bordas e de fraturas. Embora os contatos com as ultramáficas normalmente sejam mascarados por faixas de biotita xisto gerado a partir do próprio crossitito, algumas vezes observa-se uma alternância centimétrica entre essas rochas e, raramente, contatos diretos, gradacionais, indicando uma origem comum dos 

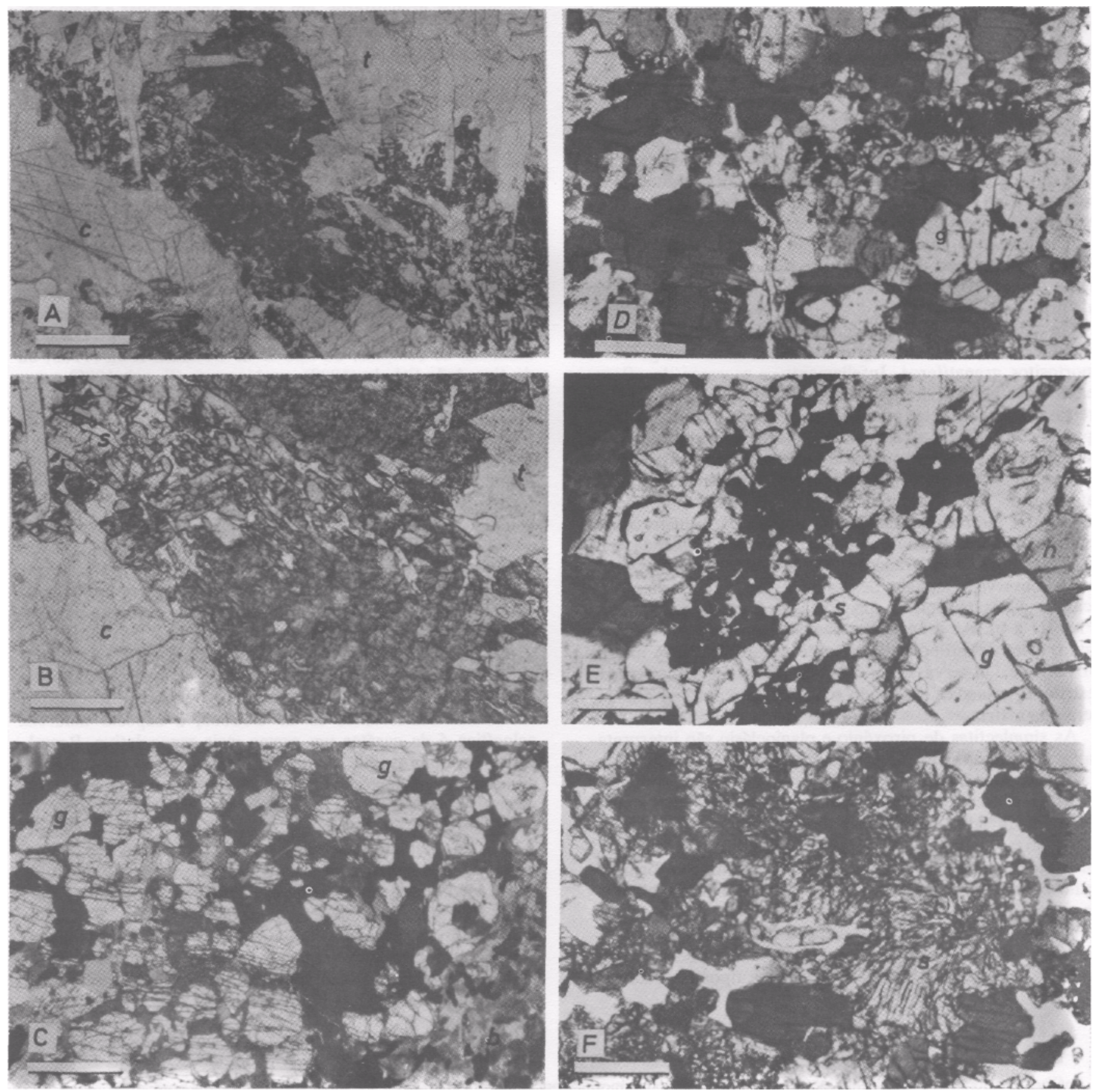

Figura 7 - Fotomicrografias de rochas eclogiticas:A e B. piroxenito com matriz tremolítica foliada, de Lagoa da Baraúna, Bodocó. Observam-se restos de onfacita (p) substituídos perifericamente por simplectita de diopsídio + plagioclásio (S), por sua vez substituidos por tremolita (t), calcita (c) elou clorita. Nic. II, barra em A =0,7 $\mathrm{mm} \mathrm{B}=0,3 \mathrm{~mm}$; C. crossitito granatifero de Riacho da Posse, Floresta, mostrando as granadas ( $g$ ) com intenso fraturamento (horizontal na foto) em matriz de crossita grossa quase não atingida pelo fraturamento e, até, aproveitando esse fraturamento para substituir a granada. No lado direito da foto, observa-se uma faixa biotitizada formada por substituição tanto da granada como da crossita. A. biotita, bem foliada, não apresenta sinais de deformação na direção de fraturamento da granada. Nic. II, barra $=0,7 \mathrm{~mm}$; D e E. anfibolito granatifero $(\mathrm{g})$ em matriz de hornblenda $(h)$ e simplectita de diopsídio + plagioclásio + ilmenita (s), esta última provável produto de retrometamorfismo de onfacita. Nic. II, barra em $D=0,7$ e $E=0,3 \mathrm{~mm}$. F. anfibolito granatifero, mostrando detalhe de simplectita de diopsídio + granada (s), sendo substituída perifericamente por hornblenda grossa $(h)$ e plagioclásio. Nic. II, barra - 0,3 mm, afloramento da ocorrência de Barragem, Floresta. No canto superior direito, grão de rutilo (preto) envolvido perifericamente por titanita.

Figure 7 - Photomicrographs of eclogitic rocks: A. and B. pyroxenites with foliated tremolitic matrix, from Lagoa da Baraúna, Bodocó. Relics of omphacite (p) are replaced first by a symplectite of diopsode 4- plagioclase (S1) and later by tremolite ( $\mathrm{t}$ ) and calcite (c) and/or chlorite, //nicols, bar in $\mathrm{A}=0.7$ and $\mathrm{B}=0.3 \mathrm{~mm}$; C. garnetiferous crossitite from Riacho da Posse, Floresta, showing intensively fractured garnets $(\mathrm{g})$ in a matrix of coarse grained crossite (almost without fractures). On the right side of the picture, both garnet and crossite are replaced by foliated biotite, not affected by the fractures, //nicols, bar $=0.7 \mathrm{~mm}$; D. and E. garnetiferous amphibolite with a matrix of hornblende (h) and symplectitic intergrowth of diopsode + plagioclase + ilmenite (S), probable pseudomorph after omphacite. //nicols, bar in $\mathrm{D}=0.7$ and $\mathrm{E}=0.3 \mathrm{~mm}$; F. garnet (g) rich amphibolite showing the detail of the symplectitic intergrowth of diopsode + plagioclase $(\mathrm{S})$ being replaced by coarse grained hornblende $(\mathrm{h})$ and plagioclase. $/ /$ nicols, bar = $0.3 \mathrm{~mm}$. Outcrop of the Barragem Fe-Ti occurrence, Floresta. In the upper-right corner a rutile grain is enveloped by a retrograde titanite rim 
crossititos e ultramáficas mineralizadas. Essa suposição é confirmada também pela presença dos mesmos minerais de minério das ultramáficas como acessórios nos crossititos (até $20 \%$ de ilmenita, magnetita, pirrotita, pentlandita, cubanita). A natureza original provavelmente eclogítica dessa rocha é indicada pela completa ausência de plagioclâsio em rocha sódico-aluminosa (composição indicada pela crossita e granada), pela própria crossita e pela completa identidade dessa rocha com os crossititos já descritos identificados em Bodocó, lá alternando com anfibolitos eclogíticos com restos de onfacita. Admite-se que os crossititos representem níveis de composição intermediária, mais suscetíveis ao metamorfísmo eclogítico, no corpo ígneo dominatemente ultramáfico, em seu restante refratário ao metamorfismo por falta de composição adequada.

Na ocorrência de Barragem, os litotipos possivelmente eclogíticos são novamente granada anfibolitos, metagabros e anortositos granatíferos. Infelizmente, a escassez de afloramentos não permite definir melhor as relações de contato enj tre essas rochas e delas com os litotipos restantes do corpo. E apenas comprovada a alternância indiscriminada entre elas garantindo uma origem primária comum. Os granada anfibolitos podem ser compostos quase exclusivamente de granada (até mais de $50 \%$ ) e hornblenda, com ilmenita como principal acessório e biotita titanífera como produto de transformação retrometamórfica tanto da granada como da hornblenda, sendo assim possível a gradação até biotita xistos. Ocasionalmente, observam-se, além desses minerais, porções simplectíticas de clinopiroxênio 4- plagioclâsio + (às vezes) ilmenita (Fig. 7D a F). As granadas novamente mostram inclusões de rutilo, além de anfibólio semelhante à hornblenda da matriz. Novamente, observa-se o intenso fraturamento orientado restrito às granadas, indicando sua formação anterior aos minerais da matriz.

As simplectitas de piroxênio e plagioclásio são interpretadas como produto de retrometamorfismo de piroxênio NaCa-aluminoso, ou seja, onfacítico, e são perifericamente transformadas em hornblenda mais grossa. Nas simplectitas que incluem adicionalmente a ilmenita, esta poderia ter-se exsolvido a partir de um piroxênio primário rico em $\mathrm{Fe}-\mathrm{Ti}$ (bronzita?) em sua transformação para onfacita sob forma de rutilo e transformadas em ilmenita durante o retrometamorfismo que provocou o break down da onfacita para diopsídio + plagioclâsio. Com a recristalização posterior a esse retrometamorfismo, gerando a hornblenda e plagioclâsio mais grossos, essas rochas podem evoluir para tipos bandados de metagabros granatíferos, em que as hornblendas e plagioclásios incluem blasticamente restos dos clinopiroxênios, granada $\mathrm{e}$, às vezes, rutilo.

DISCUSSÃO A paragênese granada-rutilo-onfacitazoisita, identificada localmente nas lentes metamáficas de Bodocó, indica um metamorfismo na fácies eclogito. Embora não seja mais muito aceita cientificamente a determinação de anfibólios e piroxênios por métodos petrográficos clássicos, no caso em questão a determinação é corroborada via difratometria de raios $\mathrm{X}$ e, texturalmente, pelo break down da onfacita formando as características simplectitas de clinopiroxênio ou ferro-glaucofânio com plagioclâsio, estas sim, encontradas genericamente nos corpos básicos em questão. Além dessa textura, toda a sucessão de fases e paragêneses metamórficas encontrada é virtualmente idêntica a outros exemplos clássicos mundiais de eclogitos do tipo C de Coleman et al. (1965) ou do tipo 4 de Eskola (1939), na Noruega (Krogh 1980) e nos Alpes Italianos (Ernst 1976,1981). As finas inclusões helicíticas de rutilo na granada permitem excluir a possibilidade de formação diretamente a partir do manto (eclogitos tipo 1 e 2 de Eskola 1939, ou A de Coleman et al. 1965). Adicionalmente, a presença de inclusões aparentemente precoces de f erro-glaucofânio na granada indicaria uma caracterização como do tipo $\mathrm{C}$, típico de limites de placas ativas, não obstante o relacionamento com encaixantes gnáissico-migmatíticas mais característicos do tipo B. Nesse sentido vale ressaltar que esta interpretação se enquadra perfeitamente no modelo de colisão sugerido por Marinho et al. (com. verb.) para o Sistema de Dobramentos do Riacho do Pontal.

$\mathrm{Na}$ ocorrência de Floresta não tendo sido encontrada a paragênese eclogítica típica completa, mas apenas relidos de granada e rutilo, assim como paragêneses e texturas retrometamórficas semelhantes às de Bodocó, a suposta natureza eclogítica é de caráter um pouco mais especulativo. Ressalte-se, no entanto, que essa ocorrência coincide em seu posicionamento geotectônico com o Bodocó, ou seja, no limite setentorial do precursor do Cráton do São Francisco (em sua configuração Pré-Brasiliana).

A idade mínima, inferida a partir do contexto geológico e datações radiométricas regionais, seria do Proterozóico Inferior a Médio para ambas as ocorrências, sendo que para o corpo de Barragem existem determinações radiométricas preliminares e duvidosas nas metamáficas (K-Ar) e de suas encaixantes que indicariam uma idade arqueana. Esses dados colocariam os eclogitos estudados entre os mais antigos conhecidos.

\section{REFERÊNCIAS BIBLIOGRÁFICAS}

ANGEL, M. \& RIERA, F. 1959. Rapport de la Mission ou Pernambouc. Bureau Minier Guynais-Service Francais de Cooperation Technique. $134 \mathrm{p}$.

BEURLEN, H. \& LIRA, R.B. 1988. Two atypical Fe-Ti occurrences at Bodocó and Floresta, State of Pernambuco, Brazil. In: CONOR. BRAS. GEOL., 35, Belém, 1988. Anais... Belém, SBG.

BRITO-NEVES, B.B., 1975. Regionalização geotectônica do Precambriano nordestino. São Paulo. 198 p. (Tese de doutorado IG/USP)

COLEMAN, R.G.; LEE, D.E.; BEATTY, L.B.; BRANNOCK, W 1965. Eclogites and eclogites: their differences and similarities. Geol. Soc. Am. Bull., 76:483-508.

ERNST, W.G. 1976. Mineral Chemistry of eclogites and related rocks from the Voltri Group, Western Liguria, Italy. Schweiz, miner. petrogr. Mitt., 56:293-343.

ERNST, W.G. 1981. Petrogenesis of eclogites and peridotites from the Western and Ligurian Alps. Amer. Mineralogist, 66:443-472.
ESKOLA, P. 1939. Die Metamorphen Gesteine. In: CORRENS, A.W. (ed.) Die Entstehung der Gesteine. Berlin, Springer, $422 \mathrm{p}$

HORIKAWA, Y; TORRES, H.H.; GOMES, H.A. MELO, C.B. LINS, C.A.; BARBOSA. A.G.; MUNIZ, M.B. 1979. Projeto Bodoco. Recife, CPRM. 33 p. (Rel. Final),

KROGH, E.J. 1980. Geochemistry and petrology of glaucophane bearing eclogites and associated rocks from Sunnfjord, Western Norway. Lythos, 13:355-380.

MENDES, V.A. 1983. Projeto Cachoeirinha-Folha Bodocó. Recife, CPRM/DNPM. $14 \mathrm{p}$.

SANTOS, EJ. \& CALDASSO, A. 1978. Síntese do conhecimento e ensaio interpretative da área do Riacho do Pontal, Nordeste do Brasil. SBG, Bol. Especial, 3:339-426.

SANTOS, E.J. COUTINHO, G.N · COSTA, M.P. RAMALHO, R. 1984. A região de dobramentos do Nordeste e a Bacia do Parnaíba, incluindo o Cráton de São Luiz e as Bacias Marginais. In: 
SCHOBBENHAUS, C.; CAMPOS, D.A.; DERZE, R.; ASMUS, H.E. Geologia do Brasil. Brasília, DNPM. p. 131-189.

SILVA, O.A.; MOTTA, A.C.; GOMES, R.A.; MENOR, E. 1984 Prospecção de jazimentos ferrotitanados. Sistemática geofísica para ampliação de reservas e descoberta de novas jazidas. In: SIMP. GEOL. NORDESTE, 11, Natal, 1984. Atas... Natal, SBG. Boi. 9, p. 13-26.

TROEGER, W.E. 1967. Optísche Bestimmung der Gesteinbildenden Minerale-Teil 2 Textband. Stuttgart, Schweizerbartsche 1967. $822 \mathrm{p}$.

VERONESE; V.F.; ORTIZ, L.R.; GONSAIEZ, S.R.; MENOR, E.;
MONTES, A.S.; MARQUES, N.M.; COUTINHO, J.B. 1985.

Projeto Ferro Titanado de Floresta, PE. Vol. 2 - Metalogenia.

Recife, Minérios de Pernambuco/Radam Brasil. 289 p.

WINKLER, H.G.F. 1965. Die Gênese der Metamorphen Gesteine. Berlin, Springer. $218 \mathrm{p}$.

MANUSCRITO A565

Recebido em 05 de junho de 1988 Revisão do autor em 13 de outubro de 1988 Revisão aceita em 17 de agosto de 1989 